\title{
ANALISIS KINERJA EKSPOR- IMPOR BUAH-BUAHAN INDONESIA PADA PERDAGANGAN INTERNASIONAL
}

\author{
Rini Hayati Lubis \\ IAINPadangsidimpuan \\ Jalan T. Rizal Nurdin Km. 4,5 Sihitang, Padangsidimpuan \\ Email : lubisrini87@gmil.com
}

\begin{abstract}
Abstrak,
Perkembangan nilai impor tahun 2017 untuk komoditi buah-buahan di Indonesia mengalami peningkatan dibandingkan tahun sebelum, hal ini menunjukan bahwa adanya peningkatan dalam jumlah konsumsi buah-buahan, sedangkan untuk jumlah produksi buahbuahan di Indonesia juga mengalami peningkatan di tahun 2017. Maka dari itu penelitian bertujuan untuk menganalisis kinerja ekspor-impor buah-buahan Indonesia pada perdagangan internasional. Hasil dalam penelitian menunjukan bahwa berdasarkan nilai rata-rata Indeks Spesialisasi Perdangangan (ISP) sebesar -0,455583904 artinya bahawa Indoensia masih negara impotri dan memiliki dayang yang lemah terhadap perdagangan komoditi buah-buahan, untuk nilai rata-rata Import Dependecy Ratio sebesar 2,8 persen artinya bahwa negara indonesia tidak ketergantungan pada impor buah dengan membandingkan nilai Self Sufficiency Ratio sebesar 98 persen, sedangkan nilai revealed comperatif advantage sebesar 0,095 dan nilai Revealed Symetric Comperatif Advantage sebesar -0,825 artinya Indonesia tidak memiliki keunggulan komperatif yang masih rendah.
\end{abstract}

Kata Kunci : Indeks Spesialisasi Perdangangan, Import Dependecy Ratio, Indeks Komperatif (Revealed Comperatif Advantage-RCA dan Revealed Symetric Comperatif Advantage- RSCA)

\begin{abstract}
,
The development of import value in 2017 for fruit commodities in Indonesia has increased compared to the previous year, this shows that there is an increase in the amount of fruit consumption, while for the amount of fruit production in Indonesia also increased in 2017. Therefore The study aims to analyze the performance of Indonesian fruit exports and imports in international trade. The results of the study show that based on the average value of the Trade Specialization Index (ISP) of -0.455583904 it means that Indonesia is still an impotent country and has a weak lady in the fruit commodity trade, for the average Import Dependecy Ratio of 2, 8 percent means that the Indonesian state is not dependent on fruit imports by comparing the Self Sufficiency Ratio value of 98 percent, while the revealed comparative advantage value is 0.095 and the Revealed Symetric Comperative Advantage value of -o.825 means that Indonesia does not have a low comparative advantage.
\end{abstract}




\section{ANALISIS KINERJA EKSPOR- IMPOR BUAH-BUAHAN INDONESIA PADA PERDAGANGAN INTERNASIONAL \\ Rini Hayati Lubis}

\section{PENDAHULUAN}

Ekspor dan impor merupakan salah satu kegiatan ekonomi yang memiliki peranan yang penting bagi kehidupan suatu negara, tujuan dari ekpor yaitu mengendalikan harga produk ekspor, menciptakan iklim usaha yang kondusif, dan menjaga kestabilan kurs valuta asing sedang tujuan dari impor memenuhi kebutuhan dalam negeri, mengurangi keluarnya devisa keluar negeri serta memperkuat posisi neraca.

Menurut (Kemendag, 2018) data sektor ekspor terdiri dari migas, non migas yang memiliki sub sektor pertanian, industri, mining. Non migas dikategorikan dalam komoditi, sedangkan impor berdasarkan golongan barang. Menurut data Kementerian Perdagangan Republik Indonesia tahun 2018 bahwa perkembangan nilai ekspor Indonesia dapat dilihat pada Gambar. 1 dibawah ini

\section{Gambar.1 Perkembangan Nilai Ekspor dan Impor Indonesia Periode 2013- 2017 Dalam Satuan Juta US\$}

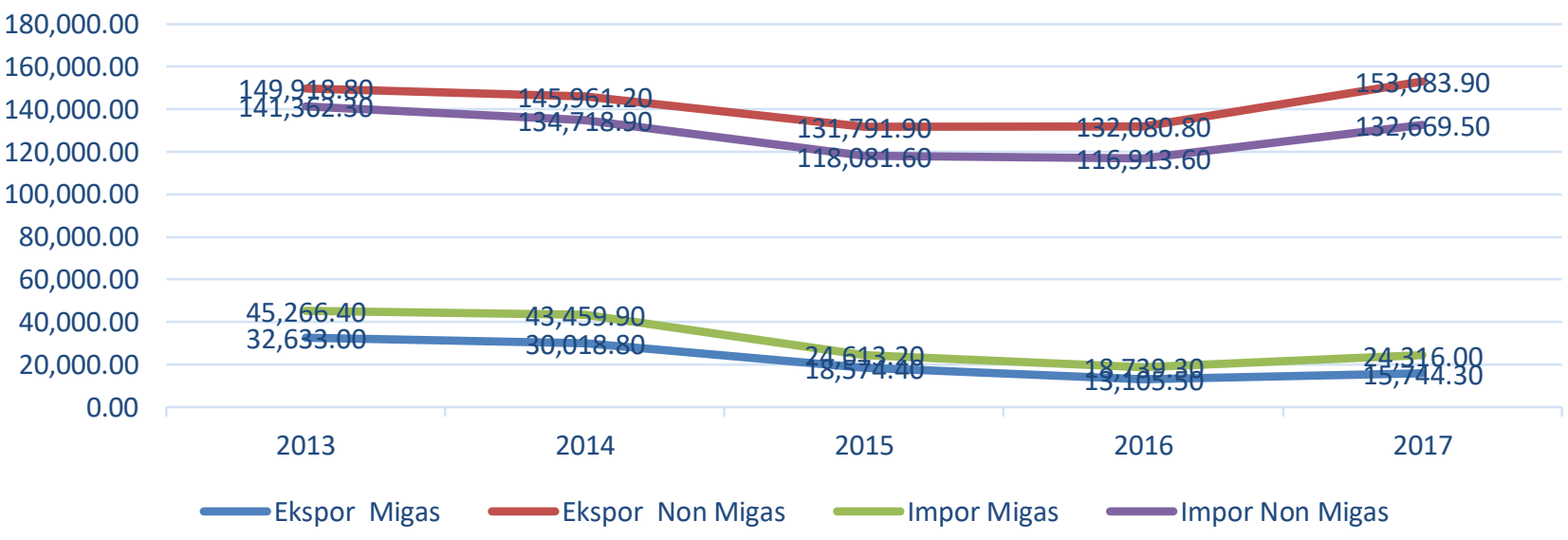

Sumber : Neraca Perdagangan Indonesia Total Kemendag 2013-2017

Berdasarkan Grafik 1, diatas perkembangan nilai ekspor dan impor tahun 2013-2017 bahwa secara keseluruhan untuk perkembangan nilai ekspor lebih dominan pada sektor non migas dibandingkan sektor migas, dimana perkembangan sektor non migas lima tahun belakang ini mengalami peningkatan, hal ini berbanding terbalik dengan perkembangan nilai ekspor migas yang lebih rendah terutama pada tahun 2016, akan tetapi perkembangan nilai impor migas lebih tinggi dibandingkan perkembangan nilai ekspor migas, sedangkan untuk perkembangan nilai impor non migas setiap tahunnya mengalami peningkatan walaupun begitu nilai ekspor non migas masih dominan dibandingkan nilai empor non migas.

Sektor non migas terdiri dari beberapa komponen salah satunya yaitu sektor pertanian, sektor pertanian memiliki dua puluh empat komoditi salah satunya komoditi buah-buahan. Saat ini perkembangan nilai ekspor buah-buahan Indonesia menurut data BPS tahun 2018 mengalami penurunan sebesar 3,2 persen dibandingkan tahun 2017 yaitu 
sebesar US\$ 398,38 juta begitu juga dengan tingkat volume ekspor buah yang mengalami penurunan sebesar 5,67 persen

Menurut Direktorat Hortikultura Kementerian Pertanian (Kemtan) penyebab terjadinya penurunan nilai dan volume ekspor buah-buahan di Indonesia disebabkan adanya pemunduran masa panen buah untuk tahun ini, walaupun produktivitas lahan menunjukan adanya kenaikan sebesar 7,1 persen yang disebabkan adanya program pemerintah dalam pengembangan kawasan yang berfokus pada komoditas unggulan. Untuk lebih jelasnya dapat dilihat pada Gambar. 2 dibawah ini

\section{Gambar.2 Perkembangan Nilai Ekspor Dan Impor Buah-Buahan IndonesiaDalam Satuan Juta US\$ Periode 2016-2018}

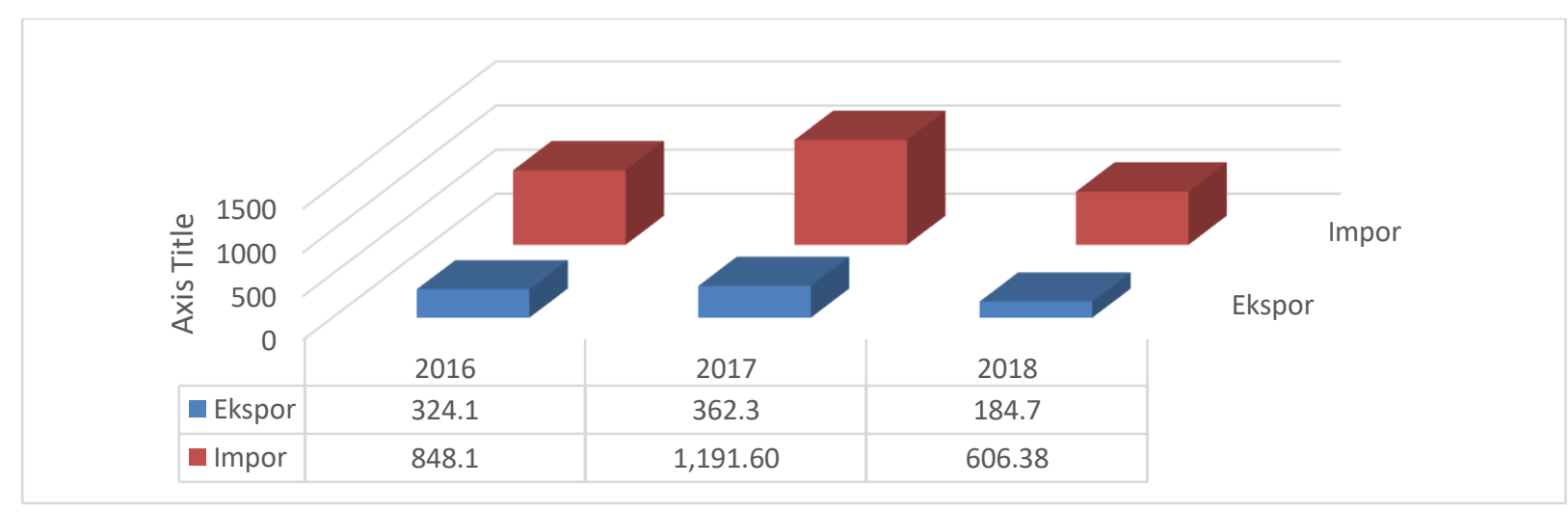

Sumber : Data Ekspor dan Impor Non Migas Kemendag 2016-2018

Berdasarkan Grafik.2 diatas nilai ekspor dan impor buah-buahan Indonesia dapat disimpulkan bahwa tingkat nilai impor buah-buahan lebih tinggi dibandingkan nilai ekspor, artinya bahwa Indonesia masih dikatagorikan sebagai negara pengimpotir terbesar dalam pemasokan komoditi buah-buahan dibandingkan dengan komoditi sayuran, produk makanan olahan, susu, telur dan mentega, padahal negara kita mampu atau memiliki daya potensi terbesar dalam meningkatkan jumlah produksi buah-buahan lokal, apalagi ditambah dengan adanya program pengembangan kawasan untuk meningkatkan produktivitas lahan tanaman buah-buahan, akan tetapi hal ini berbanding terbalik dengan kenyataannya, hal ini berdasarkan data perkembangan nilai import diatas bahwa Indonesia belum mampu menjadi negara ekspotir dalam komoditi buah-buahan

Sedangkan untuk tingkat konsumsi buah-buahan berdasarkan data (BPS, 2016) menunjukan bahwa sekitar 73,59 persen mengkonsumsi buah-buahan, artinya tingkat jumlah konsumsi untuk buah-buahan cukup tinggi, buah yang paling banyak untuk dikonsumsi adalah buah pisang dimana rata-rata konsumsi buah ini dalam seminggu sebesar 


\section{ANALISIS KINERJA EKSPOR- IMPOR BUAH-BUAHAN INDONESIA PADA PERDAGANGAN INTERNASIONAL \\ Rini Hayati Lubis}

o,113 kg dibandingkan dengan buah lainnya, tingginya tingkat konsumsi buah-buahan didorong oleh beberapa faktor salah satunya pendapat seseorang.

Peluang pasar buah-buahandi pasar internasional memiliki potensi yang cukup besar salah satunya negara Spanyol dan United States. Berdasarkan data (Kemendag, 2016) bahwa peluang pasar buah-buahan dan sayur-sayuran kaleng memiliki potensi peluang pasar yang cukup baik dimana volume perdagangan buah-buahan dan sayur-sayuran di spanyol terus mengalami peningkatan dalam lima tahun terakhir, hal ini dapat dilihat pada Tabel. 3 di bawah ini

Tabel.1Volume Pasar Buah-Buahan Dan Sayuran Kaleng Di

SpanyolDalamSatuan Ton, Periode 2011-2015

\begin{tabular}{lll}
\hline Tahun & Juta Ton & Pertumbuhan (\%) \\
\hline 2011 & 1.52 & \\
2012 & 1.56 & $2.4 \%$ \\
2013 & 1.59 & $2.2 \%$ \\
2014 & 1.80 & $12.7 \%$ \\
2015 & 1.85 & $2.8 \%$ \\
\hline
\end{tabular}

Sumber :Kemendag 2011-2015

Berdasarkan Tabel.1 di atas dapat dijelaskan bahwa pertumbuhan volume pasar buah-buahan dan sayuran untuk negara Spanyol mengalami peningkat cukup signifikan dan ini merupakan salah satu peluang pasar yang cukup menjanjikan bagi negara eksportir buah-buahan sehingga dapat meningkat jumlah produksi buah-buahan dan sayuran-sayuran lokal. Hal yang serupa dengan negara United States, dimana perkembangan nilai ekspor buah-buahan dan sayuran dari Indonesia memiliki nilai yang cukup tinggi dibandingkan dengan negara lainnya, hal ini berdasarkan data BPS tahun 2018 bahwa volume buahbuahan dan sayuran mengalami peningkatan dari tahun sebelumnyayaitu sebesar 21.309.166 kg ataudengan niali FOB US\$ 18.220.635, dan ini dapat diartikan bahwa Indonesia memiliki peluang pasar buahan-buahan dan sayuran.

Tingginya tingkat konsumsi terhadap produksi buah-buahan serta diikuti dengan ketidakseimbangan jumlah produksi buah-buahan lokal, sehingga mengharus bagi pemerintah untuk mengambil suatu kebijakan agar terpenuhi kebutuhan terhadap produk tersebut yaitu dengan cara mengimpor buah-buahan dari luar negeri sehingga menyebabkan nilai import buah-buahan mengalami peningkatan dibandingkan nilai ekspor hal ini disebabkan adanya kebutuhan terhadap produk terus meningkat dan ditambah lagi dengan adanya peluang pasar buah-buahan di perdagangan internasional yang cukup menjanjikan, 
maka dari itu penelitian bertujuan untuk menganalisis bagaimana kinerja perdagangan buah-buahan Indonesia dalam pasar perdagangan internasional.

\section{TINJUAN TEORITIK}

\section{Ekonomi Internasional}

Ekonomi internasional merupakan suatu ilmu ekonomi yang membahas akibat saling ketergantungan antara negara-negara di dunia baik dari segi perdagangan internasional maupun pasar kredit internasional. Ilmu ekonomi internasional juga termasuk dalam politik internasional, komunikasi internasional, hukum internasional dan juga merupakan implementasi dari kebijakan ekonomi domestik antara berbagai aktor dalam suatu negara dengan negara lain dalam lingkungan bilateral maupun multilateral. Pola hubungan internasional bisa berbentuk kooperatif, kompetitif maupun konfliktif, sedangkan sifat hubungan internasional bisa berbentuk interdependensi, independensi maupun dependensi. Demikian halnya dengan ekonomi internasional bahwa terciptanya perdagangan internasional dan kerjasama internasional di bidang pembangunan infrastruktur antara negara karena dilandasi hubungan yang bersifat interdependensi dan hubungan yang berpola kooperatif (Dominick Salvatore, 1994).

Menurut (Apridar, 2009) adapun manfaat dari perdagangan internasional yaitu 1). Memperoleh barang yang tidak dapat diproduksi di negara sendiri, faktor-faktor yang menyebabkan sulitnya untuk memproduksi yaitu kondisi geografi, iklim, tingkat pengusaan iptek, dan lain-lainya dengan adanya perdagangan internasional setiap negara mampu memenuhi kebutuhan yang tidak diproduksi sendiri, 2). Memperoleh keuntungan dari spesialisasi, sebab utama kegiatan perdagangan luar negeri adalah untuk memperoleh keuntungan yang diwujudkan oleh spesialisasi, walaupun suatu negara dapat memproduksi suatu barang yang sama jenisnya dengan produksi negara lain, akan tetapi kebutuhannya terhadap produk tersebut lebih tinggi dibandingkan memproduksi maka hal tersebut negara harus dapat mengimpor dari negara lain, 3). Memperluas pasar dan menambah keuntungan, 4). Transfer teknologi modren, dengan adanya perdagangan luar negeri memungkinkan suatu negara untuk mempelajari suatu teknik produksi yang lebih efesien dan cara-cara manajemen yang lebih modren.

Faktor-faktor pendorongan terjadinya perdagangan internasional antara lain 1). Untuk memenuhi kebutuhan barang dan jasa dalam negeri, 2). Keinginan memperoleh keuntungan dan meningkatkan pendapatan negara, 3). Adanya perbedaan kemampuan penguasaan ilmu pengetahuan dan teknologi dalam mengelolah sumber daya ekonomi, 4). Adanya kelebihan produk dalam negeri sehingga perlu adanya pasar baru untuk menjual 


\section{ANALISIS KINERJA EKSPOR- IMPOR BUAH-BUAHAN INDONESIA PADA PERDAGANGAN INTERNASIONAL \\ Rini Hayati Lubis}

produk tersebut, 5). Adanya perbedaan keadaan seperti sumber daya alam, iklim, tenaga kerja, budaya, dan jumlah penduduk yang menyebabkan adanya perbedaan hasil produksi dan adanya keterbatasan produksi, 6). Adanya kesamaan selera terhadap suatu barang, 7). Keinginan membuka kerja sama, hubungan politik dan dukungan dari negara lain, 8). Terjadinya era globalisasi sehingga tidak satu negara pun di dunia dapat hidup sendiri(Syamsurijal, 1990).

\section{Teori-Teori Perdagangan Internasional}

Adapun beberapa teori yang berkaitan tentang perdagangan internasional (Apridar, 2009) sebagai berikut: Pertasma, Teori Klasik Adam Smith Keunggulan Mutlak (Absolute Advantagel Absolute Cost). Pandangan teori klasik berkembang pada abad ke-18 yang dipelopori oleh Adam Smith, dia berpendapat bahwa logam mulia tidak mungkin ditumpuk dengan surplus ekspor karena logam mulai akan mengalir dengan sendirinya melalui perdagangan internasional (price specie flow mechanisme), Adam Smith tidak menginginkan adanya campur tangan pemerintah dalam perdagangan bebas, karena perdagangan bebas akan membuat orang berkerja keras untuk keperntingan negaranya sendiri dan sekaligus mendorong terciptanya spesialisasi, dengan terciptanya spesialisasi maka negara akan menghasilkan suatu produk yang memiliki keunggulan mutlak (absolute advantage). Dapat asumsi pokokkan bahwa teori keunggulan mutlak antara lain 1). Faktor produksi yang digunakan hanya tenaga kerja, 2). Kualitas barang yang diproduksi kedua negara sama, 3). Pertukaran dilakukan secara barter atau tanpa uang, 4). Biaya transfortasi diabaikan. Kedua, Biaya Relatif ( Comperative Cost : David Ricardo). Teori David Ricardo didasarkan pada nilai tenaga kerja atau theory of labor value yang menyatakan bahwa nilai atau harga suatu cost comparative produk ditentukan oleh jumlah waktu atau jam kerja yang diperlukan untuk memproduksinya. Ketiga, Teori modren keunggulan komperatif (comparative advantage) dari Model Hechsher dan ohlin. Banyak ahli menganggap bahwa teori ini merupakan kelanjutan dari teori klasik, karena essensinya sama yaitu melihat penyebab terjadinya perdagangan antara dua negara terutama pada suplly, akan tetapi teori modren melihat dari supply dan demand. Keempat, Teori Haberler. Menurut Haberler bahwa ada beberapa perbedaan penting antara teori klasik dan teori Haberler yaitu pada cost of production, dimana menurut klasik bahwa cost of production dapat meningkat disebabkan adanya pemakaian tenaga kerja yang semakin tingi yang mengakibatkan upah akan meningkat, akan tetapi menurut Haberler meningkatnya cost of production, bukan hanya disebabkan adaya peningkat jumlah kerja, melainkan adanya peningkatan kombinasi terhadap pemakaian faktor produksi. Kelima, Ongkos Oppurtunity Adalah ongkos yang dikorbankan dari memproduksi satu barang untuk memproduksi satu barang untuk memproduksi barang lainatau dapat juga dikatakan beberapa pengorbanan faktor produksi 
dapat digunakan untuk memproduksi satu barang dialihkan kepada barang lainyang dianggap mempunyai keuntungan komperative.

\section{Daya saing ekspor}

Daya saing ekspor merupakan suatu kemampuan komoditi untuk memasuki pasar bebas, serta dapat bertahan dalam pasar tersebu. Pengukuran daya saing ditinjau dari dasar perbandingan pangsa pasar komoditi terhadap kondisi pasar yang tetap, salah satu upaya untuk meningkatakandaya saing komoditi ekspor (Amir MS,2017) yaitu : Mengusahakan rasionalisasi dalam biaya produksi dan tataniaga barang-barang ekspor. Menyederhanakan atau menghapus perijinan yang dirasakan tidak sesuai lagi. Menyederhanakan prosedur lalulintas barqang dan dokumen. Mengusahakan tercapainya uang tambang yang bersaing dibandingkan dengan negara pesaing. Menyempurnakan sistem pemberian sertifikat ekspor seperti menyederhanakan produser penepatan sertifikat ekspor dan memperluaskan jenis barang yang diberikan fasilitas setifikat ekspor

Berdasarkan ayat Al-Qur'an Surah Al-Jumu'ah ayat 9-10 yang berbunyi :

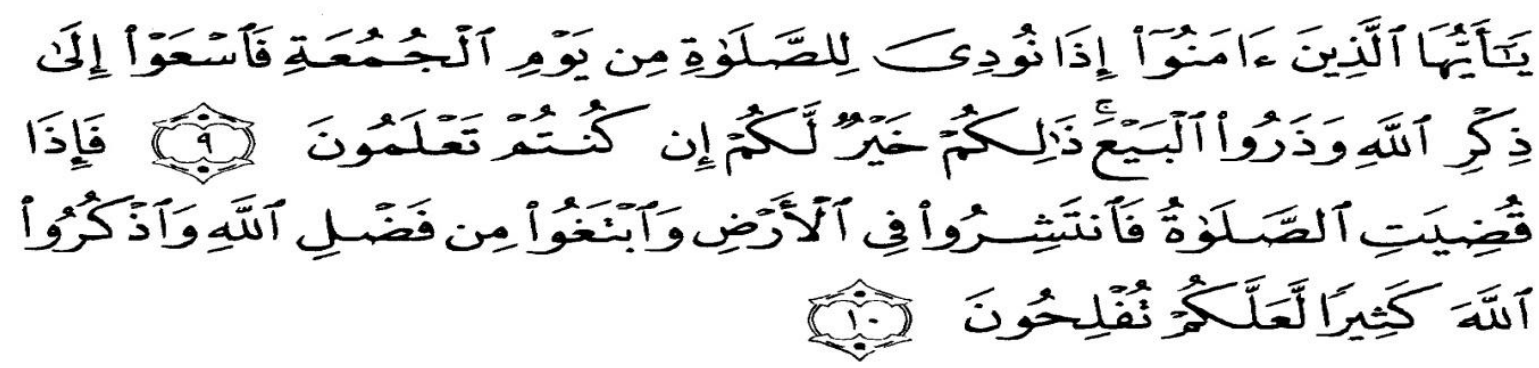

Artinya : 9. Hai orang-orang beriman, apabila diseru untuk menunaikan shalat Jum'at, Maka bersegeralah kamu kepada mengingat Allah dan tinggalkanlah jual beli[a]. yang demikian itu lebih baik bagimu jika kamu mengetahui. 10. apabila telah ditunaikan shalat, Maka bertebaranlah kamu di muka bumi; dan carilah karunia Allah dan ingatlah Allah banyak-banyak supaya kamu beruntung.

Dalam ayat diatas dijelaskan bahwa Ada dua hal yang perlu cermati yaitu fantasyiruu fi al-ard dan wabtaghu min fadl Allah, dimana redaksi fantasyiruu mengisyaratkan amr atau perintah melarang kita untuk terus berdiam diri di mushala tetapi wajib keluar dan bertebaran melakukan segenap aktivitas bisnis setelah shalat fardlu selesai ditunaikan. Akan tetapi Allah SWT tidak membatasinya hanya sekadar di kampung kecamatan kabupaten provinsi atau Indonesia saja, melainkan Allah memerintahkan untuk go global atau fi al-ard. Ini artinya kita harus menembus Eropa Amerika Australia dan Jepang. Adapun tujuan yaitu untuk mencarai rezeki yang di ridohhi oleh Allah. Ketika perintah bertebaran ke pasar global Amerika Eropa Australia dan Jepang bersatu dengan perintah berdagang di sinilah letak tantangan adanya daya saing ekspor 


\section{ANALISIS KINERJA EKSPOR- IMPOR BUAH-BUAHAN INDONESIA \\ PADA PERDAGANGAN INTERNASIONAL \\ Rini Hayati Lubis}

\section{METODE PENELITIAN}

Jenis data yang digunakan dalam penelitian adalah data sekunder dengan rentang waktu (time series) tahun 2013-2017. Sumber data yang diperoleh dari beberapa instansi seperti Biro Pusat Statistik, Kementerian Perdagangan, Kementerian Pertanian, serta sumber-sumber lainnya yang berkaitan dengan penelitian ini. Data yang digunakan adalah jumlah produksi buah-buahan dalam negeri, volume ekpor dan impor buah-buahan Indonesia

Metode yang digunakan untuk menganalisis kinerja perdagangan komoditi pertanian(Pusat data dan Informasi Pertanian, 2015) yaitu 1) Indeks Spesialisasi Perdagangan

ISP digunakan untuk menganalisis atau tahap perkembangan suatu komoditas. ISP dapat menggambarkan apakah suatu komidtas, posisi Indonesia cenderung menjadi negara ekpostir atau importir komoditas pertanian tersebut. Secara umum ISP dapat dirumuskan sebagai berikut

$$
\text { ISP }=(\text { Xia-Mia }) /(\text { Xia }+ \text { Mia })
$$

Keterangan :

Xia : Nilai ekspor komoditi i di negara j

Mia : Nilai impor komoditi i di negara $\mathrm{j}$

nilai indeks ISP memiliki kisaran sebesar -1 samapai +1, adapun kriteriad dalam nilai ISP adalah Jika nilai ISP positif diatas o sampai 1, maka komoditi bersangkutan dikatakan mempunyai daya saing yang kuat atau negara bersangkutan dikategorikan sebagai pengekspor atau suplai domestik. Jika nilai ISP negatif dan dibawah o hingga -1, maka komoditi bersangkutan dikatakan memiliki daya saing sangat rendah, dan negaranya cenderung untuk mengimport.

Untuk mengindentifikasi tingkat pertumbuhan suatu komoditi dalam perdagangan internasional terbagi atas lima tahapan. Pertama, tahap pengenalan yaitu dimana tahap kondisi industri pada suatu negara $\mathrm{x}$ mengekspor produk-produk baru dan industri pendatang belakangan di negara y impor poroduk-produk tersebut, dalam tahap ini nilai ISP adalah -1,00 sampai 0,50, artinya komoditi tersebut memiliki daya saing rendah atau negara bersangkutan adalah negara pengimpor komiditi tersebut. Kedua, tahap subtitusi yaitu memiliki nilai indeks ISP naik antara -0,51 sampai o,o0. Pada tahap ini industri negara y menunjukan daya saing yang sangat rendah, hal ini disebabkan rendahnya produksi yang mengakibatkan tidak tercapainya skala ekonominya artinya industri tersebut dapat mengekspor komoditi tersebut tetapi kualitasnya masih rendah dan produksi dalam negeri masih lebih kecil dari jumlah permintaan. Ketiga, tahap pertumbuhan, nilai indeks ISP naik antara o,o1sampai o,80 dan industri negara tersebut melakukan produksi dalam skala besar 
sehingga dapat meningkatkan jumlah ekspornya hal ini disebabkan pasar domestik penawaran untuk komoditi tersebut lebih besar dari jumlah permintaan sehingga dapat mengekspor ke negara lain, dengan kata lain bahwa tahap ini negara tersebut memiliki daya saing yang kuat dengan ditandai yaitu dapat memperluas ekspor negara tersebut. Keempat, tahapan kematangan yaitu nilai indeks berkisar antara 0,81 sampai 1,00, pada tahapan ini produk bersangkutan sudah memiliki tahap standardisasi yang berhubungan dengan teknologi yang dimilikinya, artinya negara tersebut merupakan negara net exporter atau dengan kata lain negara tersebut memiliki daya saing yang sangat kuat. Kelima, tahap kembali mengimpor, dimana nilai indeksnya mengalami penurunan antara 1,00 sampai o,oo, pada tahapan ini industri negara tersebut kalah bersaing di pasar domestik dengan industri negara lain hal ini disebakan jumlah produksi dalam negeri lebih sedikit dibandingkan jumlah permintaan dalam negeri.

Import Dependency Ratio (IDR), IDR merupakan formula yang menyediakan informasi ketergantungan suatu negara terhadap impor suatu komoditas. Nilai IDR dihitung berdasakan defenisi yang dibangun oleh FAO (Food And Agriculture Organization of the United Nations). Perhitungan nilai IDR tidak termasuk perubahan stok dikarenakan besarnya stok baik dari impor maupun produksi domestik tidak ketahui. Secara sistematinya rasio ketergantungan impor dapat dirumuskan sebagai berikut (Tambunan, 2004) :

$$
\mathrm{IDR}=((\text { Mia/Produksi }+ \text { Mia-Xia })) \times 100
$$

Keterangan :

$\mathrm{M}=$ Impor

$\mathrm{X}=$ Ekspor

$\mathrm{i}=$ Jenis Barang

$\mathrm{a}=$ Negara

Self Sufficiency Ratio (SSR), nilai SSR menunjukan besarnya produksi dalam kaitannya dengan kebutuhan dalam negeri, SSR diformulasikan sebagai berikut

$$
\mathrm{SSR}=\frac{\text { Produksi }}{\text { Produksi+Impor-Ekspor }} \times 100
$$

Indeks Keunggulan Komperatif Revealed Comperative Advantage (RCA) dan Revealead SymetricComperative Advantage (RSCA). Konsep Comperative Advantage diawali oleh pemikiran David Ricardo yang melihat bahwa kedua negara akan mendapatkan keuntungan dari perdagangan apabila menspesialisasikan untuk memproduksi produk-produk yang memiliki Comperative Advantagedalam keadaan autarky (tanpa perdagangan), dalam penelitian ini membandingkan dan meneliti hubungan daya saing buah-buahan dengan 


\section{ANALISIS KINERJA EKSPOR- IMPOR BUAH-BUAHAN INDONESIA \\ PADA PERDAGANGAN INTERNASIONAL}

Rini Hayati Lubis

negara- negara pengekspor buah-buahan khususnya negara China dan Thailand, secara simatisnya dapat dilihat sebagai berikut

$$
\mathrm{RCA}=\frac{X i j / X j}{X i w / X w}
$$

Keterangan :

$$
\begin{aligned}
& X \mathrm{Xj}=\text { Nilai ekspor komoditi } \mathrm{i} \text { di negara } \mathrm{j} \\
& \mathrm{Xj}=\text { Nilai ekspor total negara } \mathrm{j} \\
& \mathrm{Xiw}=\text { Nilai ekspor komoditi i di dunia } \\
& \mathrm{Xw}=\text { Nilai ekspor total dunia }
\end{aligned}
$$

Sebuah produk dinyatakan memiliki daya saing jika RCA $>1$ dan tidak memiliki daya saing RCA < 1 . Berdasarkan hal ini dapat dipahami bahwa nilai RCA dimulai dari o sampai tidak terhingga. Menyadari keterbatasan RCA tersebut, maka dikembangkan Revealead SymetricComperative Advantage (RSCA) dengan rumus sebagai berikut

$$
\mathrm{RSCA}=\frac{R C A-1}{R C A+1}
$$

Konsep RSCA membuat perubahan dalam penilaian daya saing, dimana nilai RSCA dibatasi antara -1 sampai dengan 1. Sebuah produk disebut memiliki daya saing jika memiliki nilai di atas nol, dan dikatakan tidak memiliki daya saing jika di bawah nol.

\section{HASIL DAN PEMBAHASAN}

Perkembangan produksi buah-buahan di Indonesia di tahun 2017 mengngalami peningkatan dibandingkan tahun sebelumnya yaitu sebesar 7,09 persen, untuk lebih jelasnya dapat dilihat pada Grafik. 3 dibawah ini.

\section{Grafik.3 Perkembangan Produksi Buah-Buahan Indonesia Tahun 2013-2017}

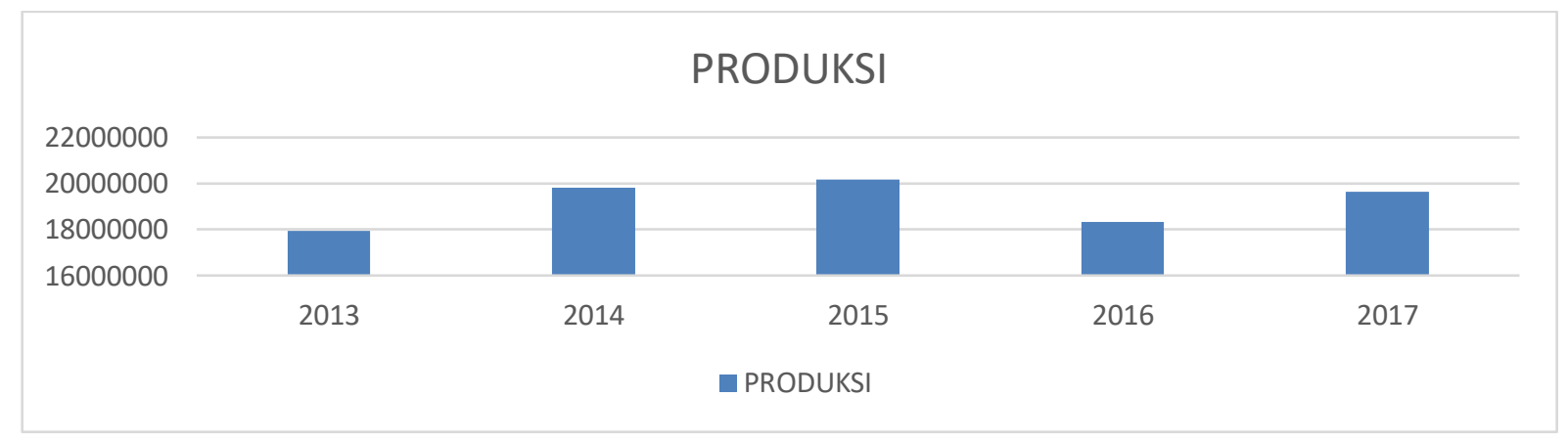

Sumber : BPS 2013-2017

Berdasarkan Grafik.3 diatas dapat disimpulkan bahwa perkembangan produksi buahbuahan mengalami peningkatan yang cukup signifikan dari tahun 2013-2015, akan tetapi di tahun 2016 mengalami penurunan dan tahun 2017 mengalami peningkatan kembali, hal ini disebabkan adanya program pemerintah dalam memfokus produktivitas lahan, dan bibit 
unggul untuk meningkatkan produksi buah-buahan lokal. Maka dari itu penelitian bertujuan untuk melihat seberapa besarnya daya saing produk buah-buahan di pasar internasional

\section{Analisis Kinerja Perdagangan Komoditi Buah-Buahan Indonesia di Perdaganan Internasional}

Kinerja perdagangan suatu komoditas dapat dilihat dari besarnya ekspor, impor yaitu diukur dari tingakat ISP, IDR, RCA, RSCA.

Indeks Spesialisasi Perdagangan, secara implisit ISP mempertimbangkan sisi permintaan dan sisi penawaran, dimana ekspor identik dengan suplai domestik dan impor adalah permintaan domestik, atau sesuai dengan teori perdagangan internasional yaitu net of surplus, dimana ekspor dari suatu barang terjadi apabila ada kelebihan atas barang tersebut dipasar domestik, untuk lebih jelasnya dapat dilihat Tabel.2 dibawah ini.

\begin{tabular}{cc}
\hline Tahun & Indeks Spesialisasi Perdagangan \\
\hline 2013 & $-0,563129539$ \\
2014 & $-0,446348392$ \\
2015 & $-0,287729469$ \\
2016 & $-0,447022692$ \\
2017 & $-0,533689427$ \\
\hline Rata-rata & $-0,455583904$
\end{tabular}

Tabel.2 Nilai Indeks Spesialisasi Perdagangan Indonesia Tahun 2013-2017 Sumber : Data diolah

Berdasarkan Tabel.2 diatas dapat dijelaskan bahwa nilai rata-rata ISP sebesar -0,455 pada periode 2013-2017, maka perdagangan komoditi buah-buahan Indonesia dikategorikan sebagai tahap pengenalan dalam perdagangan internasional atau masih memiliki daya saing rendah artinya negara Indonesia merupakan negara pengimportir buah-buahan.

Import Dependency Ratio (IDR) dan Self Sufficiency Ratio. Untuk melihat seberapa besar ketergantungan Indonesia terhadap impor buah buahan dapat dilihat pada Tabel. 3 dibawah ini 


\section{ANALISIS KINERJA EKSPOR- IMPOR BUAH-BUAHAN INDONESIA \\ PADA PERDAGANGAN INTERNASIONAL}

Rini Hayati Lubis

Tabel.3 Nilai IDR buah-buahan Indonesia Tahun 2013-2017

Tahun Import Dependency Ratio

(IDR / Persen)
Self Sufficiency Ratio

(SSR Persen)

\begin{tabular}{lcc}
\hline 2013 & 2,9 & 98 \\
2014 & 2,9 & 98 \\
2015 & 2,3 & 99 \\
2016 & 2,6 & 98 \\
2017 & 3,4 & 97 \\
\hline Rata-rata & 2,8 & 98 \\
\hline
\end{tabular}

Sumber : Data diolah

Berdasarkan Tabel. 3 dapat dijelaskan bahwa tingkat ketergantungan Indonesia terhadap produksi buah-buahan nilai rata-rata IDR menunjukan sebesar 2,3 hingga 3,4 persen sedangkan nilai SSR menunjukan sebesar 97-99 persen, artinya bahwa Indonesia sudah bisa mencukupi kebutuhan buah-buahan dalam negeri dengan proposi yang cukup besar dari produksi sendiri.

Revealed Comperative Advantage (RCA) dan Revealead SymetricComperative Advantage (RSCA). Salah satu indikator yang dapat menunjukan perubahan keunggulan komperatif adalah RSCA indeks. Indeks ini menunjukan perbandingan antara pangsa ekspor komoditi atau sekelompok komoditi suatu negara terhadap pangsa ekspor komoditi tersebut dari seluruh dunia. Dengan kata lain indeks RCA menunjukan keunggulan komperatif atau daya saing ekspor dari suatu negara dalam suatu komoditi terhadap dunia. Hasil analisis RSCA komoditi buah-buahan Indonesia untuk tahun 2017 dapat Tabel. 4 di bawah ini

Tabel.4 Nilai RCA dan RSCA Indonesia

\begin{tabular}{|r|rr|rr|}
\hline \multirow{2}{*}{ TAHUN } & \multicolumn{3}{|c|}{ INDONESIA } \\
\cline { 2 - 5 } & \multicolumn{2}{|c|}{ RCA } & \multicolumn{2}{c|}{ RSCA } \\
\hline 2017 & & 0,09578591 & \multicolumn{2}{|c}{02517401} \\
\hline
\end{tabular}

Sumber : Data Diolah

Tabel.4 menunjukan bahwa komoditi buahan Indonesia tahun 2017 mempunyai nilai RSCA kurang dari 1 berarti pada periode tersebut keunggulan komperatif buahan Indonesia rendah dan tidak memiliki daya saing selama periode tersebut, hal ini disebabkan luas lahan dan produksi belum maksimal atau masih rendah 


\section{KESIMPULAN}

Berdasarkan hasil penelitian maka disimpulkan hal-hal berikut : hasil nilai ISP diperoleh sebesar -0,455 artinya bahwa negara Indonesia masih dikategorikan sebagai pada tahap pengenalan atau juga disebut dengan negara importir serta memiliki daya saing rendah berdasarkan nilai ISP tersebut. Untuk nilai IDR menunjukan sebesar 2,3 hingga 3,4 persen sedangkan nilai SSR menunjukan sebesar 97-99 persen, artinya bahwa Indonesia sudah bisa mencukupi kebutuhan buah-buahan dalam negeri dengan proposi yang cukup besar dari produksi sendiri. Sedangkan untuk nilai RSCA sebesarnya -o,82artinya lebih kurang dari 1, artinya negara Indonesia belum memiliki keunggulan komperatif buahan Indonesia rendah dan tidak memiliki daya saing

\section{Saran}

Berdasarkan hasil penelitian, maka penelitian ini disarankan untuk lebih meningkat keunggulan komperatif dan kompetitif buah-buahan Indonesia dapat dilakukan dengan peningkatan luas lahan, meningkatkan diversifikasi, intensifikasi yang tujuan akhirnya untuk meningkat jumlah produksi buah-buahan lokal sehingga dapat menciptakan keunggulan komperatif dan kompetitif pada pasar komoditi buah-buahan di perdagangan internasional.

\section{DAFTAR PUSTAKA}

Apridar, Sejarah, 2009, Teori, Konsep Dan Permasalahan Dalam Aplikasinya Ekonomi Internasional, Yogyakarta: Graha Ilmu

Amir MS, 2007, Teori Dan Penerapannya Ekspor Impor, Seri Binis Internasional No.13, Jakarta: Sekolah Tinggi Manajemen

(BPS) Badan Pusat Statistik, 2018. Buletin Statistik Perdagangan Luar Negeri Ekspor Menurut Kelompok Komoditi Dan Negara Mei 2018. Jakarta (ID) : Badan Pusat Statistik

(BPS) Badan Pusat Statistik, 2018. Indonesia Dalam Angka. Jakarta (ID) : Badan Pusat Statistik

Dominick Salvatore, 1994, Ekonomi Internasional, Edisi Ketiga: Seri Buku Sekaum, Jakarta: Erlangga 1994

(KEMENDAG) Kementerian Perdagangan, 2018. Neraca Perdagangan Indonesia Total Periode 2013-2018 Jakarta (ID) : Kementerian Perdagangan Indonesia

(KEMENDAG) Kementerian Perdagangan, 2016. Peluang Pasar Buah-Buahan Dan Sayuran Kaleng di Spanyol 2016.Jakarta (ID) : Kementerian Perdagangan Indonesia

Pusat data dan Informasi Pertanian, 2015. Kinerja Perdagangan Komoditi Pertanian Volume 5 No.2. Pusat data dan Informasi Pertanian. Departemen Pertanian Jakarta.

Syamsurijal Tan, 1990, Esensi Ekonomi Internasional, Jakarta : Ghalia Indonesia 
ANALISIS KINERJA EKSPOR- IMPOR BUAH-BUAHAN INDONESIA

PADA PERDAGANGAN INTERNASIONAL

Rini Hayati Lubis

Tambunana TTH. 2004, Globalisasi dan Perdagangan Internasional. Bogor : Gamalia 